\title{
The threat of lingua globalization towards vernaculars in South Sulawesi
}

\author{
Ramli1 $^{*}$, Farid Helmi Setyawan', Rampeng ${ }^{2}$ \\ 1 Jurusan Pendidikan Bahasa Inggris, FKIP, Universitas Borneo Tarakan, Indonesia \\ ${ }_{2}^{2}$ Jurusan Pendidikan Bahasa Inggris, FKIP, Universitas Bosowa, Indonesia. \\ *correspondence Author: ramli26@borneo.ac.id
}

\begin{tabular}{|c|c|}
\hline ARTICLE INFO & ABSTRACT \\
\hline Keywords: & Indonesia seems to face the crisis of local language especially in \\
\hline Globalization; Lingua; & urbanization. The emergence of English as a lingua franca is \\
\hline Modernization; & undeniable to decrease the existence of vernaculars. The research aims \\
\hline Vernaculars; Culture & to reveal the reason for urbanization giving the biggest impact on the \\
\hline Heritage. & Indonesian's local language in South Sulawesi and how to maintain \\
\hline How to cite: & $\begin{array}{l}\text { the use of local language is facing extinction in this century. This } \\
\text { study applied a descriptive qualitative design by interviewing three }\end{array}$ \\
\hline Ramli., Setyawan, F.H., & subjects. They are lecturers and students. The interview result showed \\
\hline $\begin{array}{l}\text { Rampeng. (2021). The } \\
\text { threat of lingua }\end{array}$ & $\begin{array}{l}\text { that globalization is one of the plagues that had the impact on } \\
\text { vernaculars becoming threatened in this present day, influenced people }\end{array}$ \\
\hline $\begin{array}{l}\text { globalization towards } \\
\text { vernaculars in South }\end{array}$ & to obey their vernaculars and also affected the youths' psychological \\
\hline Sulawesi. ETNOSIA: & use of \\
\hline Jurnal Etnografi & government in maintaining the vernaculars particularly in South \\
\hline Indonesia. 6(1): $230-240$. & $\begin{array}{l}\text { Sulawesi. One suggestion can be proposed that local content needs to } \\
\text { be involved in the Education sector e.g., intensifying vernacular use }\end{array}$ \\
\hline $\begin{array}{l}\text { DOI: } \\
\text { 10.31947/etnosia.v6i2.18197 }\end{array}$ & $\begin{array}{l}\text { in school and family, and sustainably promoting cultural heritage to } \\
\text { attract the society. }\end{array}$ \\
\hline
\end{tabular}

\section{Introduction}

Nowadays people prefer to learn international languages for education, especially mastering the subject to speak with foreigners and to acquire a job in the future. Hence, instead of speaking in the local language, people prefer to speak Indonesian formally and English which is most popular and modern nowadays. Lauder (2008) identified that English had become an important international language for the community and teaching subject in national and international schools. The regulation of English in Indonesia might decline national culture and identity (Idris, 2014). Furthermore, this country is facing problems about how to maintain and sustain vernaculars before it will fade. Vernacular or heritage language is an intensely rooted humanitarian phenomenon. It is not separable from human reality. This is essential to admit and coincide vernacular. In addition, vernacular could efficiently attain a robust association with the standard 
language from which vernacular was invented. Each language variety is from its own fields (Khader \& Hammad, 2017).

English is related to globalization in developing countries and Indonesia is a part of it. Budi (2014) stated that vernaculars had been threatened because of the dominance of English. Internet, electronic media and movies in theatre are dominant in English already. English is the most powerful language for facing globalization (Canagarajah, 2004). Indonesia categorized English as the majority language and Lingua Franca (Kachru, 1985). The positive and negative are appearing due to this regulation which is the extinction of vernaculars in this century. English as a Lingua Franca (ELF) is languages that people often use who live among different first languages (Seidlhofer, 2002). In Indonesia, many teenagers widely used international language and adapted to their culture which is sometimes different from the identity or heritage culture. The urgency of English learning has increased along with English production in a globalized environment. English was no longer only limited to international purposes but also to local communication (Gunantar, 2016). Therefore, the focus of this research is to find whether or not lingua globalization can be a threat towards the existence of vernaculars besides exploring how to maintain vernaculars in today's situation.

\section{Literature Review}

Indonesia is a multicultural country with varieties of ethnics and costumes in South-East Asia, it is the home for more than 1700 islands and 746 original languages articulated by hundreds of ethnic groups (Widodo \& Fardhani, 2013). In history, the Indonesian language (formerly Malay) was selected among three languages, namely Malay, Javanese (local language) and Dutch (colonial language) immediately after Indonesia declared independence from Dutch colonization (Paauw, 2009). Indonesia is a famous country with different plural and languages all around. 13.677 islands and hundreds of local languages spread widely, from Sabang until Merauke (Rahmi, 2016) with approximately 220 million inhabitants (Budi, 2014). Despite the richness, it also becomes a threat to the country, especially to local languages. Nowadays, Indonesia is facing the crisis of local language especially in urbanization. Ibrahim, (2011) stated that tendency of extinction is divided into 3 categories: Moribund, Endangered, and Safe language. It is predicted that in the late 21th century only about 10 percent of 75 of 746 local languages will survive (Budi, 2014). The leading use of local languages has almost disappeared because of the economic, social and education movement. People today realized that speaking in vernacular did not give advantages in social and economic life. Every enterprise didn't require vernaculars as the requirement for hiring employees. Consequently, people would eventually be going to leave their own local languages to increase their social skills for the future. Commonly, Migration is the most significant problem because people who live in rural areas start to move into crowded cities and forget their vernacular. Lauder, (2008) investigated about 58 percent of local people who use Indonesian to speak for daily conversation. The minority language is vernacular and the majority language is a national language as well-known as Indonesian and English for the academic. The minority language diminishes original speakers and under pressure from dominant languages (Arka, 2013). 
The emergence of English as a Lingua Franca is undeniable for globalization. The higher the English language climbs in status as "the language of globalization," the more other language groups lose (Johnson, 2009). Ibrahim, (2011) described that minority languages particularly in developing countries were shrunk due to the speaker who didn't teach their children and young generation ineffectively. Furthermore, the emphasis of major languages in school is Indonesian as a formal language and English as an additional language becomes a possible threat for vernacular. Communities who live in urbanization were typically talking with the national language because it's easier to communicate and implied the meaning due to the location of Indonesia which is separated by islands and hundreds of vernaculars. The succession of Indonesian has influenced the chance of the extinction of heritage languages becoming higher (Rahmi, 2016). Moreover, local languages will be fading in the next decade. If vernaculars are continuously abandoned, language loss will appear. The loss of the language is of no great moment either for science or for human intellectual life (Hale et al. 1992). Besides, when the users stop using the language as communication within an authentic speech community, it can be considered dead, or whether it is certainly dead when the last two utterers or even the very last speaker die (Dressler, 2003). Endangerment scenarios happened in Indonesia; immigration scenario and emigration scenario (Ewing, 2014). Therefore, an "endangered" language can be called off when it is facing extinction, in tribal identity language is the most important so it should be handled seriously (Indrayani, 2011; Cohn and Ravindranath, 2014).

South Sulawesi is part of Indonesia, three vernaculars were founded which are Makassarese, Buginese, and Torajanese. Said et.al., (2007) revealed that the community uses vernaculars to communicate and also enrich Indonesia legacy. SIL (2001) stated that in South Sulawesi there are 1.600.000 native speakers. Recently, those 2 vernaculars have decreased by the people themselves because the lack of dignity to speak local language, lack of exposure of vernaculars in household, school, and the tendency to use vernacular as the native speakers have mostly disappeared. Vernaculars are in first place after Indonesian and English are in the last position (Purbo-Hadiwidjoyo, 1999). Unfortunately, people are inclined to speak Indonesian rather than Makassarese and Buginese in South Sulawesi as their daily spoken language, particularly in Makassar city. Lukman (2000) identified the percentage of people who lived in the city area 52,20\% and people who lived in the rural area was $19,15 \%$ based on the data South Sulawesi categorized in Endangered Language. This country is facing a massive plague. Therefore, vernaculars moved from the first position to the last place and if the government would not give a prominent solution, people should be worried about this phenomenon which will dissolve Indonesia's biggest legacy.

The extinction of language contains a massive implication, and the factor is not merely by the loss of the native speaker but also has to concern with the inherent factor that sticks behind the language itself, which is the culture from the speaker (Tondo, 2009). Language can be able to express cultural reality through the facts, ideas, and events, and symbols of the culture value (Widdowson \& Kramsch, 2000). The problem about the extinction of vernaculars is obviously affected by the regulation of government in Indonesia, because of the role of the vernaculars, it makes the community keep 
respecting and improving the popularity of cultural legacy in the language department. If the vernaculars are not the dominant spoken language of the country, the point of interest in vernacular could bury the main things of Indonesia's legacy.

Previous research has investigated the extinction of one particular local language. There are cause and effect, symptoms, language vitality, and finally the dominance of English as a lingua franca that threatened the local language. Ipnugraha (2013) stated that when English and Indonesian are the most spoken languages in society, it means vernaculars were being ignored. Rudiansyah and Esnender (2018) stated that language conservation is dependent on the quality of language use in everyday life. The use of Buginese in Buginese students is rather low. Students do not sustain their identity as Bugis speakers in Bandung when communicating with each other. Their use of language has been displaced by Indonesian when communicating with Bugis speakers and sometimes English to communicate with natives. Besides, Sitokdana, et. al. (2019) stated that positive change comes into a more globalized environment. Situation is the increasing modern lives of experienced people and it is possibly disastrous for the people of Indonesia, namely the degradation of cultural heritage which should be used as the main foundation of the nation's civilization. As happened in Papua, some indigenous languages have disappeared and some of them will be inexistant. Based on Badan Pusat Statistika (2011), out of 1,300 ethnic groups in Indonesia their heritage languages are in endangered situations. Under this situation it is acceptable that communities in minority languages often use Indonesian for accomplishing demanding tasks. Furthermore, people did not get the point because the local language disappeared so easily and globalization is the issue.

The purpose of this study is to reveal the threat of Lingua globalization towards the existence of vernaculars. This century, globalization and modernization should help languages and cultures in Indonesia to progress wider but truly it is eroding our ancient language. Hence, this research will find the reason and the impact of vernacular language that faces extinction, and [problem solving] offered. For example, Makassarese and Buginese are almost facing extinction because of the youngling's different perceptions about using their own mother language. The previous research has found that several languages in Indonesian are closer to vanishing. This research attempted to seek the problems and potentially gives the general comprehension of presenting the extinction of local languages.

\section{Method}

The method of this research was a descriptive qualitative design to explore the impact of lingua globalization towards vernaculars in South Sulawesi, Indonesia. Three subjects from the cultural studies as well as the native speakers of vernaculars in South Sulawesi were selected in this research. The data collection was through [semi structured] interviews. To analyze the data, the researchers summarized the interviewees' response, and lastly coded the data to answer the research question. In interpreting the data to provide comprehensive summarization of the observed phenomena, the researchers also used the library study, read some relevant books and articles based on the goal of writing. 


\section{Result and discussion}

There are some possible threats that might affect the existence of vernaculars in South Sulawesi. From the first data bellow, it was showed the threat that faced:

\section{- English is more interested than their vernaculars}

In some aspects like technology, education, business, and media, English usage leads. It causes more people concerned to learn new language like English to get involved in world development. Besides, Learning the language is affordable where social media and electronic devices can help us mastery the new language to join an increasingly interconnected world (Pomeroy, 2021).

Bugis and Makassar language has been predicted to be destroyed, because it is caused by the increasing number of people who have used Indonesian and foreign languages in their families. It triggers a baby who will grow up to follow the developments that occur. (Participant 1)

People tend to interact with many people whose native languages are different. Therefore, English is required to communicate intensively. At the same time, intensive usage of Indonesian and vernacular has decreased. However, it is possibly the benefit for some people having more than two or three languages as long as English is intensively used for global communication while heritage language is maintained as the identity and treasure from ancestors.

Besides, English gave more benefit to us which would flow from the existence of a global language. Considerably several studies have pointed to possible risks of the English language. The risk of English to vernacular as said by (Wright, 2016) at (David Crystal, 2003) Conceivably global language will impact the elite monolingual linguistic class, more satisfied and apathetic in their attitudes toward other languages. Maybe for those who have the global language and particularly those who have it as the first language will think and work more quickly. They also manipulate it to grow the advantages from those who do not have it, therefore, they create the social gap between rich and poor through the linguistic guise. A global language will make people reluctant to learn other languages and reduce the opportunity to be multilingual. Maybe it will accelerate the loss of minority languages or the ultimate risk makes all other languages needless. 'A person is sufficient to acknowledge one language to connect to someone else', the statement is sometimes debated, 'and once a world language is in place, other languages will simply die away'. Associated with all assumptions, this is the indigestible expression of linguistic ethnocentrism - the threat that some people will rejoice one language's success at the expense of others. From David's statement it means that people who can master English maybe prouder than they could speak their mother tongue. They may think that English is more important than their vernacular.

\section{- The heritage language received less attention}

The native language of Makassar has rarely been found; the people used vernaculars in modern Makassar language. "Language splits" is sometimes applied so the original vernaculars can hardly be applied in the communication process. In modern today returning to local content or customs considered as traditional language should be 
widely promoted.

The government is lacking in maintaining local content, for example, in educational institutions. There are also maybe elementary to junior high schools. Moreover, the flow of modernity is increasingly strong, with the language user community aside from using Indonesian language for interaction or other languages. (Participant 1)

In order to improve its existence, it takes cooperation from every social group to think about the impending threat. How education should involve the local content especially for parents to instill local languages for their children. When the children/ students are at home, the parents should use traditional language as well as Indonesian language to develop their communication while students will have English exposure at school to prepare for their global interaction. In fact, discrepancy happens when language transfers between the elder and the earlier generation language have deteriorated. Parents do not intensively talk to the children or family members in regional languages. The parents tend to use Indonesian language in the daily communication with their children in order to prepare their children at an early age entering the school (preschool), interacting with their surrounding neighborhood as a communication, and the parents usually introducing them to other languages (English) as a symbol of modernism and innovation. Parents assume failure if they cannot communicate appropriately in the environment and it demands children to speak Indonesian effortlessly (Sitokdana, 2017; Suktriayu, et al.,2017).

Since independence, Indonesian has increasingly been spoken as a second language by most of the population and more recently increasingly as a first language, coexisting alongside other native languages in the archipelago.

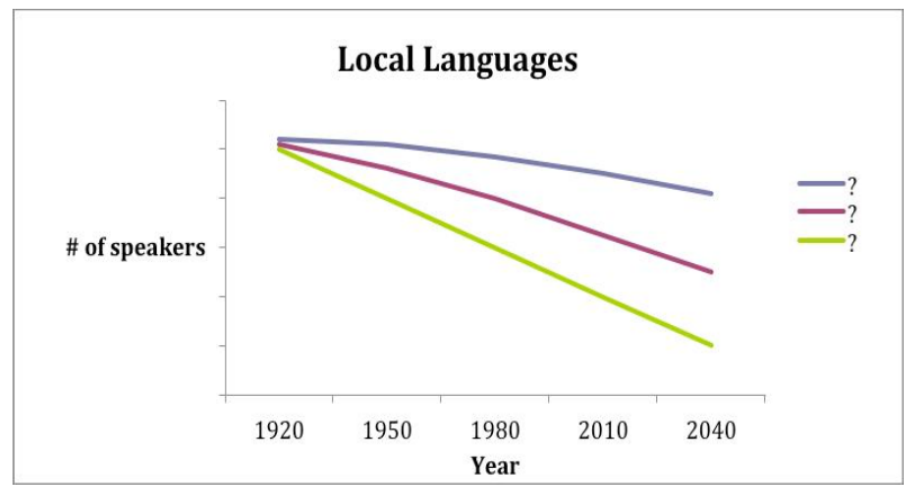

Figure 1. Effect of increase in the number of speakers of Indonesian on number of speakers of local languages (schematic)

A situation of stable bilingualism would show a relatively stable number of speakers of regional languages as the number of speakers of Indonesian increases, as schematized by the blue line; while transitional bilingualism would show a trade-off between the number of speakers of Indonesian and the number of speakers of local or regional languages as schematized by the green line (Cohn \& Ravindranath, 2014). The development and increased use of Indonesian in all spheres of society affected the use of the other native languages of Indonesia. It is considered from a variety of both "topdown" and "bottom-up" perspectives, including language policy and planning 
decisions at the national level, and multilingualism and diglossia at the local level (Cohn \& Ravindranath, 2014).

\section{- Vernacular should be proudly promoted as the identity}

Urbanization can be one of the factors. It can also be from the psychological factors of the users because once they see the language used, they do not promise anything economically. It can bring down someone's dignity, for example in Makassar when we communicate using a local dialect, it will be impressive as we are backward people. Therefore, one example of an effort to preserve heritage languages is through cultural performances.

The local language disappeared because the users are reluctant to use it to communicate. Language is wealth that must be maintained and preserved at least using in the family home environment. (Participant 2)

Preserving our local language is an appreciation for the life history of South Sulawesi and will not look like a mentally disabled person. In fact, the development of local languages from year to year has decreased because many people are urbanizing from village to city. As a result, urban areas will be affected by the language used in the city. Even if it is not sustained or developed, the language will become extinct for a very long time. This case deals with the previous study Dharma et al., (2018) who stated that "teenagers' love and appreciation to their heritage language have been gradually declined because their parents rarely use the vernacular language and even many have not used it in their home. Only a few of them still consider that possessing their identity is a long-lasting responsibility. The number of teenagers who use vernaculars as their means of communication in the regions is also very low. It is shown that they do not significantly play a role in preserving the cultures of the region since the protection is mainly done by the old. It is clear that if the old do not preserve the culture of the region, the culture may gradually vanish. Many teenagers tend to use Indonesian language or even English rather than their vernacular language in their daily communication".

\section{- Lingua globalization is part of world development}

It is undeniable that globalization is part of world development required to enable communication in an international context, English can bring positive impact for youths to boost their personal and professional growth.

In addition to globalization, factors that influence local languages are reduced, namely technological development and with the modernization of the village area which is dominant in the local community so that they will not use local languages especially in communication. (Participant 3)

Modernization and globalization are providing an opportunity for every nation to be well-developed and superior. Otherwise, if it does not have a solid and resilient identity or characters, modernization and globalization will take threats and extremes (Mulyono, 2017). The societies should have great confidence and exposure to use their vernacular to communicate in varied social interaction. In fact, many young people are shy about using local languages, so that over time they will forget their true identity as social members from the particular area. Then one solution, when communication occurs from the same area of origin, they must use the local language of the area. As recommended 
by the Governor of South Sulawesi, in every school on Friday all instruments in the school must use their local language. From the policy issued by the government, it seems that it does not provide an opportunity to create regional language teachers. Moreover, forums such as seminars that discuss regional languages are reduced. Having a large number of vernaculars in South Sulawesi can make local languages increasingly appreciated and maintained, however, on the other hand a variety of regional languages makes it difficult for people to unite so that the use of Indonesian is the solution of the unifier.

Indonesian as the national language must be officially used to communicate and unite all Indonesians from various backgrounds. Besides, vernaculars Makassarese, Bugineses, and Torajanese are the identity as well as the cultural heritage from South Sulawesi that should be sustainably and confidently promoted. This is also empowered by the statement of Indonesian Minister of Education and Culture "Lestarikan Bahasa Daerah, Utamakan Bahasa Indonesia, dan Kuasai Bahasa Asing". In line with (Johnson, 2009), although the rise of lingua francas altogether with heritage language (vernacular) can be fruitless to struggle, multilingualism has not lost its importance, and remains key in developing true cross-cultural awareness and cosmopolitanism. Thus, more should be done to promote an increase in, and earlier start to, lingual education in societies. Most importantly, however, more attention should be given to this subject, both in academia and in public life. The more we do to stay aware of the potential effects of the English language, the more we will be able to stay abreast of the best ways to maximize its benefits of having multilingual competence in social life and minimize its threat towards vernaculars. Exactly how the continued global usage of English in a globalized situation leaves its mark on the world is a question that cannot be answered today, but as an important illustration of cultural globalization that must walk hand in hand with the heritage language and identity.

Bilingualism or even multilingualism for generations has been met in many countries around the world. It should not be a burden for Indonesians to learn a vernacular in addition to Indonesians and English. Additionally, inventive ways to provide positive and attractive role models for vernacular use that appeal to young people must be found. The growth of Local language is closely related to the youth's perspectives that using vernaculars is tempting to backwardness and old fashion. There are some efforts to discover new ways to re-envisaged and re-energize the concept of local identity within the contemporary world and discovering new roles for vernaculars that re-invigorate these identities. For example, giving local language as a subject of study at school or introducing to the children about local culture. it can be very helping to maintain the richness of linguistic diversity in Indonesia as well as around the world (Ewing, 2014).

\section{Conclusion}

Lingua globalization influenced people to abandon their vernaculars and also affected the youngling's psychological order and their perception about Vernaculars. We can see today phenomena that young generation usually use modern language (slank language) in their daily communication with their friends. These phenomena are influenced more by the social media interaction. They think, if they do not follow the up-to-date 
development of information, their friends will bully them. Considering the phenomenon, Parents should encourage and transfer their cultural knowledge including the use of vernaculars to their children in their family and social life. Schools should also share the cultural value, heritage language, and local content in learning activities while they are introduced to English to prepare them for facing globalization.

Character building needs also to be integrated in learning to raise students' awareness preserving the cultural knowledge and heritage language (vernaculars). Through this research, it wishes to encourage the local language developers, teachers and parents in Indonesia especially in South Sulawesi in order to make the local language become a gateway for students' character development efforts at various levels and become a foundation for them to love and keep their vernaculars. Importantly, lingual globalization which threatens the local languages nowadays requires attention from the government to make a national campaign for preserving indigenous languages through more integrated national cultural strategies. The government should control and maintain the existence of Indonesian heritage through promoting, performing, and applying them in long-term life.

\section{Conflicts of Interest:}

The authors declare no conflict of interest.

\section{Acknowledgement:}

We thank the colleagues of English Education Department in Universitas Borneo Tarakan for providing support and guidance in completing this writing about the lingua globalization in South Sulawesi and how it had the impact on the life of heritage languages. Besides, we would like to acknowledge with gratitude the subjects of the research which provided insightful ideas towards the survival of vernaculars in South Sulawesi.

\section{References}

Arka, I. W. (2013). Language Management and Minority Language Maintenance in (eastern) Indonesia: strategic issues. Australian National University, 7(2013), 74-105.

Budi, A. S., (2014). The development of English as a lingua franca in Indonesia and the extinction of local languages. Journal of English in Academic and Professional Communication, 1(1) 59-68

Canagarajah, A. S. (2004). Reclaiming the local language policy and practice. Reclaiming the Local in Language Policy and Practice, 9(2), 1-297. https://doi.org/10.4324/9781410611840

Cohn, A. C., \& Ravindranath, M. (2014). Local languages in Indonesia: Language maintenance or language shift? Linguistik Indonesia, 32(2), 131-148.

Dharma, A. T., Lubis, W. M., \& Syahra, N. A. (2018). Teenagers Cultural Values Towards Their Vernacular and Indonesian Languages. Journal of Linguistics, Literature, and Language Teaching, 2(1), 68-77. https:/ / doi.org/10.30743/1l.v2i1.466

Ewing, M. C. (2014). Language Endangerment in Indonesia. International Journal of Education, 8 (1), 11-22

Gunantar, D.A. 2016. The impact of English as an international language on English language teaching in the Indonesian language. CIRCLE: Journal of Language and Literature, 10 (1), 141-151

Hale, K. Krauss, M. Watahomigie, L.J. Yamamoto, A.Y., Craig, C., Jeanne, L.M. and Nora 
C. (1992). Endangered Languages Linguistic Society of America. 68 (1) 1-42

Ibrahim, G. A. (2011). Bahasa Terancam Punah: Fakta, Sebab-Musabab, Gejala, dan Strategi Perawatannya. Masyarakat Linguistik Indonesia, 29(1), 35-52.

Idris, T. (2014). Language Policy and the Construction of National and Ethnic Identities in Indonesia. US-China Education, 4(10), 691-705.

Indrayani, L. M. (2011). Language Vitality: A Case on Sundanese Language as A Surviving Indigenous Language. International Seminar "Language Maintenance and Shift," 31-35.

Ipnugraha, I. (2013). Pioneering of Schools with International Standards to Respond to Globalization. Journal of Education and Learning (Edu Learn), 7(3), 153-158. https:/ / doi.org/10.11591/edulearn.v7i3.180

Johnson, A. (2009). The Rise of English: The Language of Globalization in China and the European Union. Macalester International. 22 (12), 131-168

Kachru, B. B. (1985) Standards, codification and sociolinguistic realism: the English language in the outer circle. In R. Quirk and H.G. Widdowson (Eds), English in the world: Teaching and learning the language and literatures Cambridge: Cambridge University Press.

Khader, K. T., \&Hammad, U. (2017). Towards Assessing the Vernacular in the Arabic Language: A Descriptive Analytical Study. International Journal of English Linguistics, 7(5), 164-175. https:// doi.org/10.5539/ijel.v7n5p164

Lauder, A. (2008). The Status and Function of English in Indonesia: A Review of Key Factors. Makara Human Behavior Studies in Asia, 12(1), 9-20. https://doi.org/10.7454/mssh.v12i1.128

Lukman. (2000). Pergeseranbahasa - bahasadaerahsulawesiselatan: kasuspergeseranbahasabugis, makassar, toraja, danenrekang. Universitas Hasanuddin Makassar.

Mulyono, (2017). The Problems of Modernity and Identity in the Globalization Era. Journal of Maritime Studies and National Integration, 1 (2), 106-111

Paauw, S. (2009). One Land, One Nation, One Language: An Analysis of Indonesia's National Language Policy. 5(1), 2-16.

Pomeroy, B. R. (2021). Will English Destroy All Other Languages? | Real Clear Science. 1-3 http://www.realclearscience.com/blog/2016/03/will_english_destroy_all_othe r_languages.html

Purbo-Hadiwidjoyo, M. M. (1999). Kata Dan Makna: Teman Penulis Dan Penerjemah Menemukan Kata dan Istilah. Bandung: ITB PRESS https://www.itbpress.itb.ac.id/shop/kata-dan-makna-teman-penulis-danpenerjemah-menemukan-kata-dan-istilah/

Rahmi, R. (2016). the Development of Language Policy in Indonesia. Englisia Journal, 3(1), 9-22. https:// doi.org/10.22373/ej.v3i1.622

Rabiah, S. Development of Makassarese Language Learning Materials Based on the Character-Building Concept For 5 Th Grade Elementary School Students 1. International Journal of Academic Research. 8 (6), 32-37

Said M, Thalib, F. and Ichwan. (2007). Model Perkembangan Bahasa Bahasa Daerah SulawesiSelatan. $1-11$

Seidlhofer, B. (2002). Closing A Conceptual Gap: The Case for A Description of English as A Lingua Franca. International Journal of Applied Linguistics, 11(2), 133-158.

Sitokdana, M.N.N., Tanone, Penidas, T., F. Tanaem F., (2019). Digitalization of The Local Language Dictionary of Pegunungan Bintang. Procedia Computer Science 161. 4956

Sitokdana, M. N. (2017) Mengenal Budaya Suku Ngalum Ok [Title in English: Understanding the Culture of Ngalum Ok Tribe], Salatiga: Satya Wacana Press. 
Suktriayu, R.E., Kridalaksana A.H., and Hatta, H.R. (2017) “Application of Indonesianbased Paser-Indonesian Dictionary", in Pros SAKTI (Seminar Ilmu Komputerdan Teknologi Informasi), 2 (2), 152-4.

Tondo, F. H. (2009). Kepunahan Bahasa-Bahasa Daerah: Faktor Penyebab dan Implikasi Etnolinguistis. Jurna IMasyarakat \& Budaya, 11(2), 277-296. jmb.lipi.go.id > index.php $>$ jmb $>$ article $>$ download $\% 0 \mathrm{~A}$

Widdowson, H. G., \&Kramsch, C. (2000). Oxford Introductions to Language Study-Series Editor: Language and Culture. California: University of California at Berkeley 1-71.

Widodo, H. P., \& Fardhani, A. E. (2013). The language rights of indigenous languages: an approach to maintaining Indonesia's linguistic and cultural diversity. Linguistic Diversity (p. 129).

Wright, S. (2016). Language choices: Political and economic factors in three European states. The Palgrave Handbook of Economics and Language. https:/ / doi.org/10.1007/978-1-137-32505-1 